\title{
Produksi Jerami Arbila (Phaseolus Lunatus L) Pascapanen Akibat Penambahan Level Bokashi Feses Sapi dan Chromolaena yang Berbeda
}

\author{
Bernadete Barek Koten*, Yukendi A. Sufmera, Agustinus Semang, Redempta Wea, \\ Melkianus Dedimus Same Randu, Aholiab Aoetpah \\ Jurusan Peternakan Politeknik Pertanian Negeri Kupang \\ Jln. Adisucipto Penfui, Kota Kupang Nusa Tenggara Timur Indonesia \\ *Email korespondensi: bernadete_koten@yahoo.com
}

(Diterima 05-03-2020; disetujui 05-09-2020)

\begin{abstract}
ABSTRAK
Arbila merupakan legume pakan yang jeraminya merupakan pakan hijauan yang berkualitas bagi ruminansia, dan produksi jeraminya ditentukan oleh kualitas tanah. Level bokashi yang ditambahkan mempengaruhi kualitas tanah, yang tentu berdampak pada produksi jerami arbila. Penelitian bertujuan untuk mengevaluasi produksi jerami arbila pasca panen akibat pemberian level bokashi yang berbeda. Penelitian tersebut telah dilaksanakan selama 5 bulan di Desa Noelbaki. Rancangan percobaan yang digunakan adalah rancangan acak kelompok (RAK) dengan 5 perlakuan dan 4 ulangan, terdiri atas $\mathrm{P} 0=$ tanpa bokashi (kontrol), $\mathrm{P} 10=$ penambahan bokashi 10 ton/ha, $\mathrm{P} 20=$ bokashi 20 ton/ha, $\mathrm{P} 30=$ bokashi 30 ton/ha, $\mathrm{P} 40=$ bokashi 40 ton/ha. Variabel yang diamati adalah produksi bahan segar jerami (PBSJ) (ton/ha), produksi bahan kering jerami (PBKJ), produksi bahan organik jerami (PBOJ) arbila. Data yang diperoleh dianalisis varians dan dilanjutkan dengan uji Duncan. Hasil analisis varians menunjukkan bahwa level pemberian pupuk bokashi berpengaruh sangat nyata $(\mathrm{P}<0,01)$ terhadap PBSJ arbila serta berpengaruh nyata $(\mathrm{P}<0,05)$ terhadap $\mathrm{PBKJ}$ dan PBOJ arbila. Berdasarkan hasil penelitian, diketahui rataan PBSJ arbila berkisar 0,46-2,52 ton/ha, PBKJ arbila berkisar 0,07-0,18 ton/ha, dan PBOJ arbila berkisar 0,04-0,16 ton/ha. Hasil uji Duncan menunjukkan bahwa nilai PBSJ, PBKJ dan PBOJ arbila tertinggi terdapat pada perlakuan P40. Disimpulkan bahwa semakin meningkatnya level bokashi Chromolaena dan feses sapi, produksi jerami arbila semakin tinggi. Level bokashi feses sapi dan Chromolaena terbaik adalah 40 ton/ha.
\end{abstract}

Kata kunci: arbila, bokashi, jerami, hijauan

\begin{abstract}
Arbila's straw is a quality feed for ruminants. Production of these straw is determined by soil quality. The level of bokashi added influences the quality of the soil and therefore influences the straw production. This research aimed to evaluate arbila's straw production post-harvest in different levels of bokashi. This research was carried out for 5 months at Noelbaki. The experimental design used was a randomized block design (RBD) with 5 treatments and 4 replications consisting of $\mathrm{P} 0=$ without bokashi (control), $\mathrm{P} 10=$ addition of 10 tons of bokashi / ha, P20 = 20 tons of bokashi / ha, P30 = 30 tons of bokashi / ha, P40 = bokashi 40 tons / ha. The observed variables were the straw fresh weight production (SFW) (tons/ha), straw dry matter production (SDM) (tons/ha), straw organik matter production (SOM) (tons/ha). Data were analyzed for variance and continued with Duncan test. Analysis of variance showed that the level of bokashi fertilizer had a very significant effect $(\mathrm{P}<0.01)$ on SFW and significantly affected $(\mathrm{P}<0.05)$ SDM and SOM. The average SFW in this study ranged from 0.46 to 2.52 tons/ha, HDM ranges from 0.07 to 0.18 tons/ha, and SOM ranges from 0.04 to 0.16 tons/ha. Duncan's test shows that the highest SFW, SDM and SOM are found in P40. It was concluded that arbila's straw production increases with the level of Chromolaena and cattle manure bokashi added. Highest production was shown in group with 40 ton/ha bokashi.
\end{abstract}

Keywords: bokashi, forage, Phaseolus lunatus L, straw

\section{PENDAHULUAN}

Ternak ruminansia akan berproduksi secara maksimal jika tersedia pakan hijauan yang berkualitas secara cukup dan berkelanjutan. Ternak ruminansia khususnya sapi potong di Provinsi Nusa Tenggara Timur (NTT) memiliki jumlah populasi sebesar 1.007.608 (BPS, 2018). Potensi tersebut perlu didukung melalui upaya pengembangan 
pakan hijauan yang adaptif serta dapat berproduksi secara baik pada kondisi alam di NTT.

Legum arbila (Phaseolus lunatus L.) merupakan salah satu leguminosa lokal yang biasa digunakan sebagai pakan ternak ruminansia di Provinsi NTT. Arbila merupakan legum merambat yang memiliki kemampuan adaptasi cukup luas terhadap lingkungan tumbuh, mampu berproduksi dengan baik pada daerah dataran rendah maupun tinggi, serta tahan terhadap kekeringan. Koten et al. (2012) melaporkan bahwa hijauan arbila mengandung $11,67 \%$ bahan kering (BK), 13,48\% abu, 21,21\% protein kasar (PK), 3,79\% lemak kasar (LK), dan 24,21\% serat kasar (SK). Kulit polong arbila mengandung 18,80\% PK, 0,6\% LK, $4 \%$ abu, $17,5 \%$ SK, dan $59,1 \%$ bahan ekstrak tanpa nitrogen (BETN). Kadar nutrisi yang terdapat pada biji arbila adalah 27,32\% PK, 2,18\% lemak kasar, 3,90\% abu, $5,19 \%$ serat kasar, dan 61,40\% BETN (Koten et al., 2019). Setelah dipanen bijinya, jerami arbila berupa batang dan daun tersisa masih dapat dimanfaatkan sebagai pakan hijauan bagi ternak ruminansia.

Tanah yang merupakan media tanam bagi legum arbila sangat penting untuk keberlangsungan proses pertumbuhan dan perkembangan. Kualitas fisik, kimia, dan biologi tanah akan menentukan jumlah hara dan pemanfaatan hara tersebut oleh tanaman. Perlu dilakukan berbagai upaya untuk meningkatkan kualitas tanah, dan pemberian pupuk kandang sapi pada lahan pertanaman sangat bermanfaat sebagai sebagai unsur hara tambahan bagi tanaman pakan (Syamsudin et al., 2016).

Wea et al. (2017) melaporkan bahwa pupuk kandang sapi dan gulma pastura seperti Chromolaena dapat diolah menjadi bokashi, yang mengandung $1,18 \%$, nitrogen dan $0,87 \% \quad \mathrm{P}_{2} 0_{5}$. Bahan organik dalam bentuk bokashi berbahan dasar gulma pasture alam (Chromolaena) dan kotoran sapi ini jika ditambahkan mempengaruhi kualitas tanah. Jumlah bahan organik yang terekspresi dalam level bokashi akan berpengaruh pada kualitas fisik, kimia, dan biologi tanah, yang akan berdampak pada produktivitas legume arbila yang tumbuh di atasnya, termasuk produksi hijauan jerami setelah bijinya dipanen. Hingga saat ini, informasi mengenai produksi jerami arbila (Phaseolus lunatus L) setelah pemanenan biji, sebagai dampak dari penambahan bokashi gulma Chromolaena dan kotoran sapi pada level yang berbeda belum tersedia.

Penelitian ini bertujuan untuk mengevaluasi produksi jerami arbila pasca panen akibat pemberian level bokashi yang berbeda.

\section{MATERI DAN METODE}

Bahan yang digunakan dalam penelitian ini meliputi benih arbila yang berasal dari wilayah Amarasi, media tanam berupa lahan seluas $8 \times 10 \mathrm{~m}$ $\left(80 \mathrm{~m}^{2}\right)$, Chromolaena dan feses sapi sebagai bahan baku pembuatan bokashi, EM4 (Effective Microorganism-4), gula pasir, pupuk NPK, air bersih untuk menyiram tanaman, amplop koran, spidol, dan insektisida. Alat-alat yang digunakan dalam penelitian yaitu timbangan pegas merk Camry berkapasitas $10 \mathrm{~kg}$ dengan kepekaan $0,5 \mathrm{~kg}$ untuk menimbang bokashi, timbangan digital merk Camry berkapasitas $5 \mathrm{~kg}$ dengan kepekaan $1 \mathrm{~g}$ untuk menimbang pupuk dan jerami, parang, sabit, ember, gayung, terpal, kantong bokashi, sekop, saringan tanah diameter $0,5 \mathrm{~cm}$, karung plastik, oven pengering, literan, dan meteran. Preparasi sampel dilakukan di Laboratorium Teknologi Pakan Ternak Politeknik Pertanian Negeri Kupang.

Prosedur penelitian diawali dengan pembuatan bokashi. Bokashi dibuat dari hijauan Chromolaena yang telah dicacah dan dianginanginkan serta feses sapi yang telah dijemur hingga kering. Kedua bahan tersebut kemudian ditimbang (100 kg hijauan: $10 \mathrm{~kg}$ feces). Larutan EM4 dibuat (EM4 1 liter + $200 \mathrm{ml}$ gula air/molases yang dicampur hingga homogen dalam 5 liter air) dan dipercikan pada material bokashi, dimasukan ke dalam kantung bokashi dan difermentasi selama 21 hari, dengan pembalikan setiap minggu (Wea et al., 2017).

Tanah dibongkar dan dibuat plot berukuran 2 x $1 \mathrm{~m}$, dengan 4 lubang tanam berjarak $1 \times 0,5 \mathrm{~m}$. Pupuk bokashi sesuai perlakuan diberikan pada 7 hari sebelum tanam. Setiap lubang ditanami 5 biji arbila. Penjarangan dilakukan pada hari ke 14 dengan meninggalkan 2 tanaman terbaiknya. Pupuk NPK diberikan $50 \mathrm{~kg} / \mathrm{ha}$. Pemeliharaan tanaman dan pengendalian hama terus dilakukan hingga pemanenan biji dan jerami. Panen jerami dilakukan setelah $80 \%$ polong yang dihasilkan telah matang. Pada saat panen, jeraminya dipotong sepanjang 20 $\mathrm{cm}$ dari permukan tanah, dipisahkan antara batang dan daun, dimasukan dalam kantong koran yang telah diketahui beratnya kemudian dikeringkan dalam oven dengan suhu $55^{\circ} \mathrm{C}$ hingga mencapai berat konstan, dan ditimbang. Sampel jerami selanjutnya digiling menggunakan saringan dengan diameter lubang saringan $1 \mathrm{~mm}$, kemudian dianalisis kadar bahan kering dan bahan organik (AOAC, 2010).

Penelitian ini terdiri dari 5 perlakuan dan 4 ulangan. Metode yang digunakan adalah eksperimental berdasarkan rancangan acak kelompok (RAK). Perlakuan yang dicobakan adalah: $\mathrm{P} 0=$ tanpa bokashi (kontrol), P10 : 10 ton 
bokashi/ha, P20 : 20 ton bokashi/ha, P30 : 30 ton bokashi/ha, dan P40 : 40 ton bokashi/ha. Variabel yang diamati dalam penelitian, meliputi:

a. Produksi bahan segar jerami arbila (ton/ha).

Diperoleh dari bobot segar jerami arbila termasuk batang, daun, dan polong, ditimbang sesaat setelah dipanen kemudian dikonversikan ke ton/ha.

b. Produksi bahan kering (BK) jerami arbila (ton/ha).

Diperoleh dari hasil perkalian antara BK total (BK lab x BK udara) dengan bobot segar jerami kemudian dikonversikan ke ton/ha.

c. Produksi bahan organik (BO) jerami arbila (ton/ha).

Diperoleh dari hasil perkalian antara kadar bahan organik hasil proksimat dengan bobot segar jerami kemudian dikonversikan ke ton/ha.

Data yang diperoleh kemudian dianalisis varians dan dilanjutkan dengan Uji Duncan (Duncan Multiple Range Test). Software yang digunakan sebagai alat bantu adalah Statistical Package for the Social Sciences (SPSS) versi 21.

\section{HASIL DAN PEMBAHASAN}

\section{Keadaan Umum Penelitian}

Rata-rata suhu selama penelitian ini adalah $28^{\circ} \mathrm{C}$ pada pukul 06.00 WITA, $35^{\circ} \mathrm{C}$ pada pukul
12.00 WITA, dan $27^{\circ} \mathrm{C}$ pada pukul 18.00 WITA. Berdasarkan data hasil analisis tanah pada Tabel 1, $\mathrm{pH}$ tanah berada pada kisaran $\mathrm{pH}$ yang direkomendasikan oleh Suharlina dan Abdullah (2012) yaitu $\mathrm{pH}$ yang normal untuk pertumbuhan tanaman pakan adalah 6,6-7,3.

Selama penelitian terlihat bahwa tanaman arbila dapat hidup di daerah tropis seperti NTT dan mampu bertahan hingga akhir musim kemarau. Tanaman arbila yang mendapat bokashi nampak lebih subur dibandingkan dengan yang tidak mendapat pupuk bokashi (kontrol). Tanah menjadi lebih lembab di sekitaran tanaman yang diberikan pupuk bokashi dibandingkan dengan tanaman yang tidak diberikan pupuk bokashi. Pada lahan yang tidak diberikan bokashi, air akan mengalir menjauh dari rumpun tanaman ketika disiram, sedangkan pada lahan yang diberikan bokashi air akan merembes masuk ke dalam tanah disekitar tanaman.

\section{Pengaruh Perlakuan Terhadap Produksi Jerami Arbila}

Analisis varians menunjukkan bahwa perlakuan berpengaruh sangat nyata $(\mathrm{P}<0,01)$ terhadap produksi bahan segar, serta berpengaruh nyata $(\mathrm{P}<0,05)$ terhadap produksi bahan kering dan produksi bahan organik jerami arbila.

Tabel 1. Hasil analisis tanah dan bokashi saat penelitian

\begin{tabular}{ccccccccc}
\hline Sampel & $\begin{array}{c}\mathrm{N} \text { total } \\
(\%)\end{array}$ & $\begin{array}{c}\mathrm{P} 205 \\
(\mathrm{ppm})\end{array}$ & $\mathrm{K}(\mathrm{me} / 100 \mathrm{~g})$ & $\begin{array}{c}\mathrm{C} \text { Org } \\
(\%)\end{array}$ & $\begin{array}{c}\text { Pasir } \\
(\%)\end{array}$ & $\begin{array}{c}\text { Debu } \\
(\%)\end{array}$ & $\begin{array}{c}\text { Liat } \\
(\%)\end{array}$ & $\mathrm{pH}$ \\
\hline $\begin{array}{c}\text { Tanah } \\
\text { Latosol }\end{array}$ & 0,19 & 28,20 & 0,15 & 6,13 & 23,45 & 62,20 & 14,35 & 6,6 \\
Bokashi & 0,09 & 4,94 & 1,23 & - & - & - & - & 7,4 \\
\hline
\end{tabular}

Sumber: Laboratorium Tanah Balai Pengkajian Teknologi Pertanian Nusa Tenggara Timur (2019)

Tabel 2. Pengaruh perlakuan level bokashi yang berbeda terhadap bobot segar, bahan kering, dan bahan organik jerami arbila

\begin{tabular}{lccc}
\hline \multirow{2}{*}{ Perlakuan } & \multicolumn{3}{c}{ Rata -rata produksi (ton/ha) } \\
\cline { 2 - 4 } & Bahan segar & Bahan kering & Bahan organik \\
\hline P0 (tanpa bokashi) & $0,46^{\mathrm{d}}$ & $0,18^{\mathrm{b}}$ & $0,08^{\mathrm{c}}$ \\
P10 (bokashi 10 ton/ ha) & $1,01^{\mathrm{c}}$ & $0,07^{\mathrm{c}}$ & $0,04^{\mathrm{d}}$ \\
P20 (bokashi 20 ton/ ha) & $1,35^{\mathrm{c}}$ & $1,23^{\mathrm{a}}$ & $0,10^{\mathrm{bc}}$ \\
P30 (bokashi 30 ton/ ha) & $1,88^{\mathrm{b}}$ & $1,20^{\mathrm{a}}$ & $0,13^{\mathrm{b}}$ \\
P40 (bokashi 40 ton/ ha) & $2,52^{\mathrm{a}}$ & $1,15^{\mathrm{a}}$ & $0,16^{\mathrm{a}}$ \\
\hline
\end{tabular}

Keterangan: ${ }^{a, b, c, b c, d}=$ Superskrip yang berbeda pada kolom yang sama menunjukkan perbedaan yang nyata $(\mathrm{P}<0,05)$ 
Uji Duncan menunjukkan bahwa produksi bahan segar, bahan kering dan bahan organik jerami arbila tertinggi terdapat pada P40 (bokashi 40 ton/ha) yang berbeda nyata $(\mathrm{P}<0,05)$ dengan perlakuan lainnya, kecuali pada produksi bahan kering arbila memperlihatkan perbedaan yang tidak nyata $(\mathrm{P}>0,05)$ dengan $\mathrm{P} 30$ dan $\mathrm{P} 20$. Produksi jerami terendah terdapat pada $\mathrm{P} 0$.

Hasil penelitian ini membuktikan bahwa pemberian bokashi berbahan feses sapi dan Chromolaena dapat meningkatkan produksi jerami tanaman arbila. Lebih lanjut hasil penelitian juga membuktikan bahwa semakin meningkatnya dosis bokashi hingga level 40 ton/ha, makin meningkatkan produksi jerami arbila.

Rata-rata produksi bobot segar tanaman arbila pada penelitian ini berkisar dari 0,46 sampai 2,52 ton/ha (90,25 sampai 503 g/rumpun). Hasil penelitian ini lebih tinggi dari produksi bobot segar tanaman indigofera yang dibudidaya dalam pertanaman kelapa, dipanen pada umur 90 hari setelah tanam yaitu $1,07 \mathrm{ton} / \mathrm{ha}(0,96 \mathrm{~kg} /$ pohon dengan jarak tanam $3 \times 3 \mathrm{~m}$ ) seperti yang dilaporkan oleh Takdir et al. (2019)

Rata-rata produksi bahan organik jerami arbila dalam penelitian ini berkisar antara 0,04 sampai 0,16 ton/ha. Hasil penelitian ini jauh lebih rendah dari yang dilaporkan Koten, et al. (2013) bahwa produksi bahan organik tanaman arbila yang ditumpangsari dengan sorgum dan penambahan inokolum rhizobium berkisar antara 1,08 sampai 2,53 ton/ha. Hal tersebut disebabkan karena pada penelitian ini pemanenan dilakukan ketika tanaman sudah berbuah dan bahan organik yang terdapat pada bagian vegetatif telah mengalami translokasi ke biji.

Tingginya produksi bahan segar, bahan kering, dan bahan organik jerami arbila pada perlakuan P20, P30 dan P40, dapat terjadi karena dengan meningkatnya level bokashi akan meningkatkan tersedianya $\mathrm{N}, \mathrm{P}$ dan $\mathrm{K}$ yang akan digunakan oleh tanaman dalam proses fotosintesis. Unsur hara tersebut harus selalu tersedia dalam tanah maka perlu disuplementasikan dengan bahan organik seperti pupuk bokashi. Berkaitan dengan tingginya produksi bahan organik pada perlakuan P40 disebabkan karena bahan organik yang diproduksi oleh tanaman arbila dan disimpan pada hijauannya berasal dari bahan organik dalam tanah.

Homer et al. (2017) menjelaskan bahwa untuk memperbaiki tanah yang terdegredasi dilakukan dengan cara penambahan bahan organik, karena penggunaan pupuk organik dapat mengikat unsur hara yang mudah hilang dan juga sangat membantu dalam menyediakan unsur hara tanah.
Penambahan pupuk organik seperti pupuk kandang sapi meningkatkan produksi tanaman pakan (Suarna et al., 2019).

\section{KESIMPULAN DAN SARAN}

Peningkatan level bokashi chromolaena dan feses sapi meningkatkan produksi jerami arbila. Level bokashi feses sapi dan cromolaena terbaik adalah 40 ton/ha.

\section{DAFTAR PUSTAKA}

[AOAC] Association of Official Analytical Chemists. 2010. Official Methods of Analysis of the Association of Official Analytical Chemists. Published by the Association of Official Analytical Chemists. Maryland.

[BPS] Badan Pusat Statistik. 2018. Nusa Tenggara Timur dalam Angka. BPS NTT, Kupang.

Gomez, K.A. \& A.A. Gomez. 2010. Statistical Procedures for Agricultural Research (Prosedur Statistik Untuk Penelitian Pertanian. Alih bahasa oleh E. Syamsuddin dan J. S. Baharsyah). Edisi Kedua. UI Press. Jakarta.

Homer, V., A. Ali, \& A. Maruapey. 2017. Pengaruh Pemberian Jenis Pupuk Organik Bokashi Terhadap Produksi Tanaman Jagung Manis (Zea mays Saccarata Lin.). Jurnal Median IX(3):28-35.

Koten, B. B., R. D. Soetrisno, N. Ngadiyono, \& B. Soewignyo. 2012. Forage productivity of Arbila (Phaseolus lunatus) at various levels of rhizobium. J Indonesian Trop Anim Agric 37(4): 286-293.

Koten, B.B. 2013. Penampilan produksi hijauan hasil tumpangsari arbila (Phaseolus lunatus) dan sorgum (Sorghum bicolor) pada jarak tanam arbila dan jumlah baris sorgum. Jurnal Sains Peternakan. 11(1):26-33.

Koten, B.B., R. Wea., \& A. Semang. 2019. Produktivitas Biji Arbila (Phaseolus lunatus L.) Sebagai Pakan Dengan Penambahan Berbagai Level Bokashi Berbahan Gulma Pastura Alam. Politeknik Pertanian Negeri Kupang.

Suarna, I W., I K.M Budiasa, T.I. Putri, N.P. Mariani, \& M. Hartawan. 2017. Potensi BioSlurry Dalam Peningkatan Karakteristik Tumbuh Dan Produksi Pastura Campuran Pada Lahan Kering Di Desa Sebudi Karangasem. Jurnal Pastura 6(2):70-73 
Suharlina \& L. Abdullah. 2012. Peningkatan Produktivitas Indigofera Sp. Sebagai Pakan Hijauan Berkualitas Tinggi Melalui Aplikasi Pupuk Organik Cair: Produksi Hijauan Dan Dampaknya Terhadap Kondisi Tanah. Jurnal pastura 1(2):39-43

Syamsuddin, Takdir Saili, Asmar Hasan. 2016. Hubungan pemberian pupuk kandang sapi dengan peningkatan kandungan protein dan serat kasar legum clitoria ternatea sebagai hijauan pakan ternak. Jurnal Ilmu dan Teknologi Peternakan Tropis 3(2):81-86.
Wea R. B. B. Koten, B. Ndoen. 2017. Pengaruh jenis hijauan non palatable Padang penggembalaan terhadap kandungan $\mathrm{N}$ Total dan $\mathrm{P}_{2} \mathrm{O}_{5}$ Bokashi. Prosiding Seminar Nasional ke-1 Pusat Penelitian dan Pengabdian kepada Masyarakat Politeknik Pertanian Negeri Kupang. Hal. 145-147.

Takdir M, Wardi, \& A.B.L. Ishak. 2019. Pertumbuhan dan produksi 3 jenis leguminosa pohon di pertanaman kelapa pasca defoliasi. Jurnal Ilmu Peternakan Terapan 2(2):39-43. 